\title{
Revisiting Determinants of Financial Development? The Role of Financial and Monetary Freedom: Empirical Evidence from the
}

\section{Asia-pacific Region}

\author{
Wajid Ali * $\quad$ Asif Javid ${ }^{\dagger} \quad$ Shakeel Ahmad $\ddagger \quad$ Nauman Ahmad $\S$ \\ Aamir Khan I
}

\begin{abstract}
This study aims to assess what determines/improves the overall multidimensional nature of the financial development index and its sub-indices. For this purpose, we use data over the period 1998 to 2017 for 9 countries from the Asia-Pacific region. The hypothesis of no longrun relationship between variables is tested via the three-panel co-integration test i.e. Kao test, the Pedroni test, and the Johansen test. We also examine the impact of these variables on each index through long-run dynamic estimation. We utilize FMOLS and DOLS for this purpose. All the three-panel co-integration tests suggest a long-run relationship among variables. Findings from long-run dynamic estimation indicate that efficient regulation of financial services and control over prices by the government significantly influences the financial depth, financial efficiency, and financial access indices. The financial freedom index measured by regulation of financial services negatively influences the indices, suggest that too much government regulation could distort the market. Also, an increasing probability of default of the country's banking system adversely affects the sub-indices of financial development. These findings suggest that too much government regulation of financial services and control over prices along with default of country banking system could worsen the country's financial development situation and vice versa. The promulgation of prudent regulatory policies by financial regulatory institutions is the need of the time to ensure full access to financial services, soundness, and stability of the financial sector.
\end{abstract}

Keywords: Financial Development, Financial regulations, financial inclusion, Panel Cointegration, FMOLS, DOLS, Causality.

\section{Introduction}

The role of financial liberalization/freedom and the government effort to control price stability through intervention in financial markets in determining financial development/stability are not fully explored. In the literature there exist a diverse debate on the subject relationship. Some believe that financial freedom could strengthen overall financial development

\footnotetext{
* Department of Economics, University of Perugia, Italy. Email: wajidkhan2272@gmail.com

† Sustainable Development Policy Institute, Islamabad

‡Qurtaba University, Peshawar.

$\S$ Pakistan Institute of Development Economics, Islamabad.

$\mathbb{I}$ Bureau of Emigration and Oversees Employment, Islamabad.
} 
which has its impact on contributing to the long-run economic growth (Bekaert, Harvey, \& Lundblad, 2005; Henry, 2000). But on the other hand financial liberalization as well as the excessive and unnecessary intervention of the government to make sure price stability in the economy is considered as one of the reasons behind crises in the banking sector and fragility of the financial system. The empirical evidence on the subject relationship is inconclusive. The recent debate on the relationship between bank competition and financial stability suggests that financial freedom through bank competition negatively influences financial stability. According to the 'competition fragility' view the higher the bank competition, the lower will be the incentives for banks to behave sensibly. In contrast, the 'competition stability view' maintains that the increased bank competition following financial liberalization could increase financial stability because the more the competition is the less is the incentives for banks to peruse riskier projects (Boyd \& De Nicolo, 2005).

Financial regulation besides its positive ${ }^{1}$ role in improving the financial inclusion of the country can impede the provision of financial services. The notable unpleasant consequence of excessive financial regulations is that it hampers the intermediation role of financial institutions and as a result discourages financial inclusion (Kodongo, 2018). For instance, banks are either closed or compelled to merge with other banks in case of capital deficiency. The entry into the banking sector is discouraged, with insufficient funds available to commercial banks for lending. This low credit availability triggered by strict financial regulation creates a rent-seeking environment, thereby credit availability is restricted only to successful candidates at a higher interest rate. The result is low financial inclusion. Another indicator of regulatory measure i.e. corporate tax rate is rarely investigated in the panel data context to examine its relationship with financial development. In developing countries, due to a large proportion of the informal economy, a higher corporate tax rate initially discourages financial development and after some threshold level of corporate taxation, the relationship gets reverse.

The previous studies in this area of research either examine the impact of financial liberalization on banking stability or the impact of financial regulation on financial inclusion. They also examine the indirect impact of financial freedom on financial development through changes in public debt (Bui, 2018). There exist single-country studies that examined the relationship between financial regulations and financial inclusion (Kodongo, 2018). The problem in a single country study is that their results can be implemented only to the country for which the analysis is done so the results cannot be generalized to other countries. In other words, the results derived from the panel data study can be generalized to more than one country However, no study examined the impact of variables determined either by the government or non-government regulatory agencies on overall financial development and its sub-indices.

The effective and efficient use of regulation policies for strengthening the financial system is a big concerned for practitioners. Although, developed economies already use the insights taken from their investigation of the impact of financial regulation on financial development, in the context of the less developed region such as Asia-pacific the literature ignored the empirical investigation of the link between financial regulation and financial

\footnotetext{
${ }^{1}$ Maintaining market integrity, preventing distortions to competition, reducing information asymmetry and mitigating negative externalities.
} 
development. Our contribution in this paper is manifold. First, we determine the long-run relationship between the financial regulatory environment of the country and the overall financial development index. Next, we extend our analysis to explore its relationship with the sub-indices of the overall financial development index. The foremost is that we make use of seven models by utilizing the financial freedom index and monetary freedom index to explore its long-run relationship with seven financial development indices developed by International Monetary Fund (IMF, 2016). To strengthen the relationship between financial regulation and different proxies of financial development, the study also incorporates the bank Z-score. Moreover, the study also incorporates the factors that control for bank-efficiency and business efficiencies environments such as bank non-performing loans and corporate tax rates. These variables are identified as determining factors of financial development.

The study applied a six-panel unit root test to determine the order of integration of the variables and a three-panel co-integration test to test whether the long-run relationship exists or not among the variables in the seven models of the study. Moreover, the FMOLS and DOLS methods are used to examine the long-run dynamic relationship in seven models of the study. All three co-integration tests utilized in this study suggest that there is a long-run relationship among the variables under consideration. We find that the impact of government regulation of financial services proxies by financial freedom and monetary freedom and bank-specific variables varies when we change the dependent variable of the model. For example, the impact of financial freedom and monetary freedom is positive on the financial market depth index, overall financial development index, and financial market access index while negative on the financial institution access index. In models 4,5 , and 6 financial and monetary freedom is negatively and positively associated with the dependent variable respectively. It is worth noting that monetary freedom improves all indices of financial development.

\section{Literature Review}

A plethora of literature exists that examined various aspects of financial development. Financial development can be determined from some economic variables and in a similar way it can be considered as a determinant for some other macroeconomic variables. Different studies used different macroeconomic variables as a determinant of financial development. Also, different studies use different measures of financial development to examine different dynamic relationships. Studies findings also differ in terms of magnitude and direction of the relationship between financial development and various macroeconomic variables. In this section, we tried to summarize the past literature in terms of determinants of financial development, the different measures of financial development that are used in the finance literature and the underlying relationship between three kinds of independent variables and the different measures of financial development we use as dependent variables in our study.

Several factors affect financial development which are been grouped in the literature in various ways. The literature suggests different categories of financial development de- 
terminants. For example, according to Voghouei et al. (2011), there are five categories of financial development including legal traditions, financial liberalization, institutions, political economy factors, and openness policy. On the other hand, Badeeb, Lean, et al. (2017) extended the list and included some fiscal, monetary and natural resource dependence groups of factors. The complete list comprises macroeconomic stability, institutions, financial liberalization, openness, fiscal policy, public ownership, the legal system, social capital, natural resource dependence, and human capital. The higher and unstable inflation rate can lead to inefficiency in equity and banking markets and as a result crisis in the country (Bittencourt, 2012; Boyd, Levine, \& Smith, 2001). Similarly, Law, Azman-Saini, and Ibrahim (2013); Beck, Demirgüç-Kunt, and Levine (2006) showed that good quality of institutions plays a pivotal role in financial development. They stress that institutions should be strong enough to protect the right and meet the needs of the investors. Some authors added financial liberalization and trade openness to the list of determinants of financial development. They maintained that a country's financial system gets stronger and more competitive when the country is more open to foreign trade and involved in larger capital flows. People invest more in financial markets, having greater access to financial institutions and using more financial products in countries where the level of social trust is high and vice versa. Regarding fiscal policy, the literature suggests that behind crowding out of private investment one reason is the excessive public debt. This is more serious especially in emerging economies where the financial system is not that sound (Christensen, 2005). Some studies found that there are some non-economic factors such as political instability, religious and legal factors as well as language and ethnic factors that significantly influence financial development (Huang, 2010; Roe \& Siegel, 2011). In each country, the protection and enforcement of investors' rights is defined by culture. Recent studies by Bhattacharyya and Hodler (2014); Gylfason and Zoega (2006) concluded that dependence on natural resources of a country also plays a crucial role in determining the level of financial development.

The financial sector in any country is not a single entity. It consists of markets, institutions, instruments along with a legal and regulatory framework. For a better understanding of the impact of financial development on other sectors of the economy, a good measure of it is inevitable. Since financial development has several dimensions, therefore it cannot be captured via a single measure. The World Bank framework measures four dimensions of financial development through four proxy variables including access, financial depth, stability, and efficiency which are then measured for financial markets and financial institutions.

Measuring the financial health of any economy, different studies around the world used different measures of financial development and econometric methods. The ratio of liquid assets to GDP is one of the oldest and popular measures of financial development and has been used by McKinnon (1973) and King and Levine (1993). Other standard measures of financial development that are widely used in the literature are the proportion of credit provided by banking and another financial intermediary to the private sector. The efficiency of the financial system is captured by many measures. For example, Beck, Demirgüç-Kunt, and Levine (2000) used two measures of financial efficiency 1) the ratio of overhead cost ratio to total bank assets and 2) the net interest margin which is equal to the difference 
between bank interest income and interest expenses over total assets. A higher value of the first measure suggests inefficiency while a higher value of the second measure indicates a lack of competition among banks. Some of the well-known proxies used for measuring the financial depth of the country are stock market turnover ratios measured as the ratio of trades in domestic shares to market capitalization and stock market capitalization to GDP ratio. Antzoulatos et al (2008) used a different group of variables for measuring four categories of financial indices including financial institution index, banks index, bond market development, and the stock market. For measuring bank index, they used the variables of deposit money bank assets to GDP, bank's concentration, bank overhead costs, private credit issued by domestic money bank, and bank's net interest margin. For the construction of the development of the financial institution index, life insurance premium and non-life insurance premium variables were used. To measure the financial depth in 13 OECD countries, Neusser (1998) utilized the pension funds, loan and savings association, investment banks, life and casualty insurance, and banks to construct the index. Rousseau and Wachtel (1998) use different variables for measuring financial development in five major industrial countries including Sweden, Norway, the United States, Canada, and the United Kingdom. They used the following variables for measuring their financial development index assets of commercial banks, composite of assets of commercial banks, insurance companies, savings institutions, and pension funds, and combined assets of saving institutions and commercial banks.

Apart from the quantitative measure of financial development, some studies used regulatory efficiency measures such as monetary freedom, financial freedom, and corporate tax rate as well as bank-specific measures of financial development to examine its impact on various macroeconomic variables (Ivanović \& Stanišić, 2017). Other studies that used monetary freedom to gauge its impact on economic growth include. In contrast, Carlsson and Lundström (2002) found that there is no role of monetary freedom in determining the economic activity of a country. Söderlund and Tingvall, (2017) developed their own capital/financial freedom index for China Provinces by utilizing the following proxy; financial market openness and development, such as the soundness of stock market institutions, intra-bank competition, and the share of non-state-controlled listed companies to explore its impact on economic growth. The study finds that capital freedom is positively associated with income levels in China's provinces. Bui (2018) examined the impact of financial freedom on domestic public sector debt in the Asia-pacific region and utilized the panel smooth transition regression approach. The results of the study suggest that higher financial freedom lesser will be the crowding-out effect of domestic public sector debt. For Sub-Sahara Africa, the impact of financial stability measured by bank Z-score and bank non-performing loans to gross loans on financial inclusion index constructed from the number of banks accounts, number of ATMs, borrowers from commercial banks, number of bank branches, number of depositors with commercial banks and number of commercial bank branches. The study finds that it improves the index of financial inclusion. Financial freedom and financial openness increase bank risk-taking in both developed and developing countries.

The research in the area of financial development is growing over time covering the various dimensions of financial development and its relationship with macroeconomic vari- 
ables. Based on the studies undertaken so far it can be safely said that most of them examined how financial development is related to other macroeconomic variables. The opposite relationship is explored by a very less number of studies and if studied used only one or mostly two measures of financial development. Moreover, they did not examine the impact of regulatory efficiency measures such as monetary freedom, financial freedom as well as the impact of the corporate tax rate on various measures of financial development. The contribution of this study lies in this context to explore the long-run relationship between these regulatory efficiency measure variables and some bank-specific variables with different measures of financial development.

\section{Econometric Methods}

We begin our panel data analysis from cross-sectional dependence (CD) test between the units. Which generation of unit root test i.e. first generation, second generation, or third generation we should use in our analysis can be determined from the results of the cross-sectional dependence test. Cross-sectional dependence, in general, is caused by many factors such as integration of financial and economic markets across countries, the correlation among residuals, unforeseen shocks such as oil prices shock, and global financial crises shock together with some observed and unobserved omitted common factors. If not taken into account cross-sectional dependency during analysis, can lead to several issues such as size distortion, spurious results, and biasedness in stationarity results.

Figure 1

Selection of Estimation Techniques

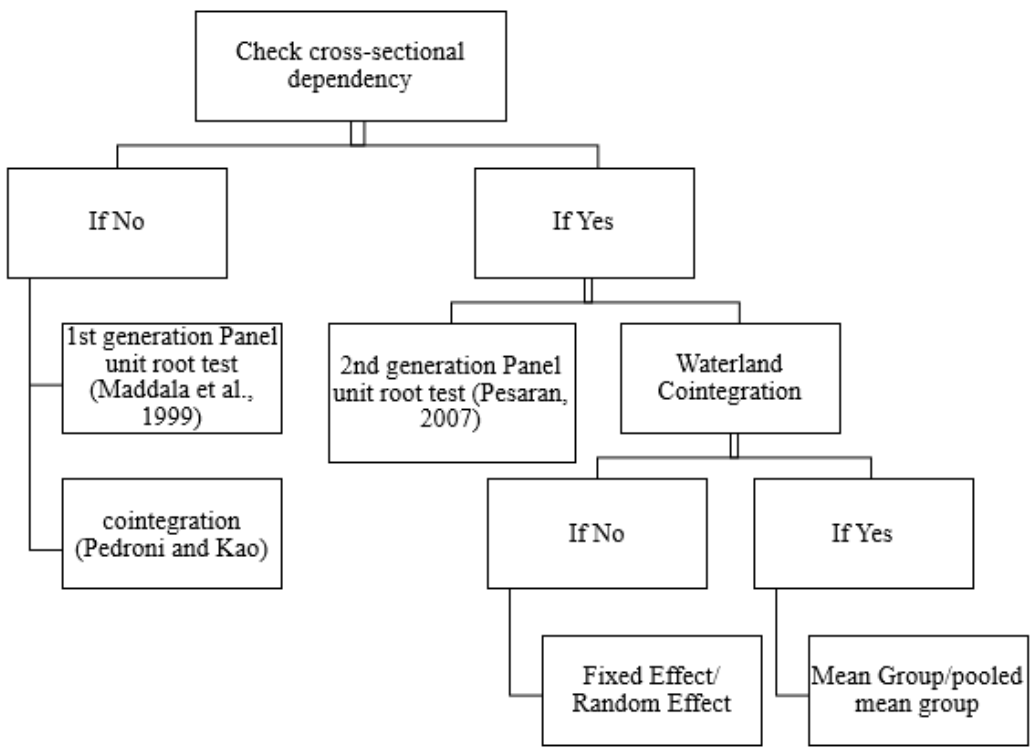


We will employ the Pesaran, (2004) test to test whether cross-sectional dependency exists in our case or not. Three types of tests are employed to test whether cross-sectional dependency exists in our case or not. The general null hypothesis for these tests is that no cross-sectional dependence exists in the data (Pala, 2019). This study has a large timeseries panel data $\mathrm{T}>\mathrm{N}$, so we used Pesaran CD test. This test is the most appropriate choice for macro panel data and has better qualities rather than all other above tests. It covers all drawbacks of Breusch and pagan (1980) LM test, Pesaran scaled LM test which is the extension of BP (1980) LM test, Balagti et al (2012) bias correlated LM test. The results of the test show that cross-sections are independent ${ }^{2}$.

\section{Panel Unit Root Test}

To avoid spurious regression, the stationarity of data is checked through panel unit root test. Two well-known panel unit root processes are the common unit root process and individual unit root process. In the former, the persistence parameters are common across cross-sections while in the latter the persistent parameters freely move across the crosssection. Levin, Lin, and Chu (LLC) employ the assumption of a common unit root process to check the stationarity of data. Similarly, I'm, Pesaran, and Shin (IPS), Fisher-ADF, and Fisher-PP employ the assumption of individual unit root process to check the stationarity of data. We use these four-unit root tests in our case and the results are provided in Table 4 of section 4 .

\section{Panel Co-integration Tests}

There are three most commonly used techniques for the analysis of panel co-integration test, i.e. Co-integration technique introduced by Pedroni (1999), Co-integration analysis presented by Kao (1999) which is Engle Granger's two-step residual-based method, and the one that is introduced by Fisher which is also known as combined Johansen Co-integration test. A brief detail of these three methods is given below.

\section{Panel Co-integration Test based on Pedroni residual}

Pedroni (1999) runs seven-panel co-integration test statistics, out of these statistics, three are based on between-dimension \& four are based on within-dimension.

The null hypothesis for the between-dimension of no co-integration is given as follows:

$$
\begin{gathered}
H_{0}: \nu_{i}=1 \text { for all } i \\
H_{0}: \nu_{i}=\nu<1 \text { for all } i
\end{gathered}
$$

Similarly, the null hypothesis of no co-integration for the within-dimension is expressed as given below:

\footnotetext{
${ }^{2}$ Results are available on demand
} 


$$
\begin{aligned}
& H_{0}: \nu_{i}=1 \text { for all } i \\
& H_{0}: \nu_{i}<1 \text { for all } i
\end{aligned}
$$

Initially, the regression residuals are computed from the hypothesized co-integration regression. In a typical way, we can illustrate the model as:

$Y_{(i, t)}=\alpha_{i}+\Delta_{i} t+\beta_{1 i} X_{(1 i, t)}+\beta_{2 i} X_{(2 i, t)}+\ldots+\beta_{m i} X_{(m i, t)}+\operatorname{epsilon}_{(i, t)} \quad t=1, . . T ; i=1, \ldots N$

Where $\mathrm{M}$ refers to the number of regression coefficients, 'T' shows the number of observations over time, \& $\mathrm{N}$ represents the number of individual members in the panel. Here $\mathrm{X}$ and $\mathrm{Y}$ are supposed to be integrated of the first order. The coefficient slopes that are $\beta_{1 i}, \beta_{2 i}, \ldots \beta_{m i}$ and particular intercept $\alpha_{i}$ differ throughout the panel of individual members. To estimate the residuals from the above equation, the seven Padroni's statistics are given below among which four are based on within-dimension \& last three are based on between-dimension:

\section{Panel $\gamma$-statistics:}

$$
T^{2} N^{3 / 2} Z_{\widehat{Y} N, T}=T^{2} N^{3 / 2}\left(\sum_{i=1}^{N} \sum_{t=1}^{T} \widehat{L}_{11 i}^{-2} \widehat{\epsilon}_{i . t-1}^{2}\right)^{-1}
$$

Panel $\sigma$-Statistics:

$$
\left.T \sqrt{N Z_{\varrho} \varrho, T^{-1}}=T \sqrt{N}\left(\sum_{i=1}^{N} \sum_{t=1}^{T} \widehat{L}_{11 i}^{-2} \widehat{\epsilon}_{i . t-1}^{2}\right)^{-1} \sum_{i=1}^{N} \sum_{t=1}^{T} \widehat{L}_{11 i}^{-2}\left(\widehat{\epsilon}_{i . t-1}\right) \delta \widehat{\epsilon}_{i, t}-\widehat{\Lambda}_{i}\right)
$$

Panel t-Statistics:

$$
Z_{t N, n}=\left(s_{N, T}^{2} \sum_{i=1}^{N} \sum_{t=1}^{T} \widehat{L}_{11 i}^{-2} \widehat{\epsilon}_{i . t-1}^{2}\right)^{-1 / 2} \sum_{i=1}^{N} \sum_{t=1}^{T} \widehat{L}_{11 i}^{-2}\left(\widehat{\epsilon}_{i . t-1}^{2} \delta \widehat{\epsilon}_{i, t}-\widehat{\Lambda}_{i}\right)
$$

Panel t-Statistics:

$$
Z *_{t N, n}=\left(s_{N, T}^{* 2} \sum_{i=1}^{N} \sum_{t=1}^{T} \widehat{L}_{11 i}^{-2} \widehat{\epsilon}_{i . t-1}^{* 2}\right)^{-1 / 2} \sum_{i=1}^{N} \sum_{t=1}^{T} \widehat{L}_{11 i}^{-2}\left(\widehat{\epsilon}_{i . t-1}^{* 2} \delta \widehat{\epsilon}_{i, t}^{*}\right)
$$

Group $\sigma$-Statistics:

$$
T N_{Z \widehat{\varrho}^{-N, T^{-1}}}^{-1 / 2}=T N^{-1 / 2} \sum_{i=1}^{N}\left(\left(\sum_{t=1}^{T} \widehat{\epsilon}_{i . t-1}^{* 2}\right)^{-1} \sum_{t=1}^{T}\left(\widehat{\epsilon}_{i . t-1} \delta \widehat{\epsilon}_{i, t}^{*}-\widehat{\Lambda}_{i}\right)\right)
$$




\section{Group t-Statistics:}

$$
N_{Z_{t, N, T}}^{-1 / 2}=N^{-1 / 2} \sum_{i=1}^{N}\left(\varsigma_{i}^{2}\left(\sum_{t=1}^{T} \widehat{\epsilon}_{i . t-1}^{2}\right)^{-1 / 2} \sum_{t=1}^{T}\left(\widehat{\epsilon}_{i . t-1} \delta \widehat{\epsilon}_{i, t}-\widehat{\Lambda}_{i}\right)\right)
$$

Group t-Statistics:

$$
N_{Z_{t, N, T}^{*}}^{-1 / 2}=N^{-1 / 2} \sum_{i=1}^{N}\left(s_{i}^{* 2}\left(\sum_{t=1}^{T} \widehat{\epsilon}_{i . t-1}^{* 2}\right)^{-1} \sum_{t=1}^{T}\left(\widehat{\epsilon}_{i . t-1}^{*} \delta \widehat{\epsilon}_{i, t}^{*}\right)\right)
$$

Pedroni provides that the standardized statistic is asymptotically normally distributed as expressed below:

$$
\frac{\aleph_{N, T}-\mu \sqrt{N}}{\sqrt{\nu}} \rightarrow N(0,1)
$$

The standardized form of the test statistics concerning $\mathrm{N}$ and $\mathrm{T}$ is given by $\aleph_{N, n}$ while $\mu$ and $\nu$ are Monte Carlo-generated adjustment terms.

\section{Kao (1999) Co-integration Tests}

Kao (1999) introduced two tests for panel data for the null hypothesis of no co-integration, namely the Augmented Dickey-Fuller type test and Dickey-Fuller Type test. Two sets of specifications in the case of the Dickey-Fuller type test are discussed below. Kao considers the following model in the case of the bivariate model:

$$
\begin{gathered}
y_{i t}=\alpha_{i}+\beta X_{i t}+e_{i t}, \\
y_{i t}=y_{i t-1}+u_{i t} \\
x_{i t}=x_{i t-1}+\epsilon_{i t} \\
\text { Where } \mathrm{i}=1, \ldots \mathrm{N}, \mathrm{t}=1 \ldots \mathrm{T}
\end{gathered}
$$

$\alpha_{i}$ is the intercept representing the fixed effect changing through the cross-section observations, $\beta$ shows the slope parameters, $y_{i t}$ and $x_{i t}$ are independent random walks for all i. The residual series $\epsilon_{i t}$ must have to be integrated of order one I(1).

Kao estimated residuals from the above equations and for the Dickey-Fuller test the following equation applies to the estimated residuals

$$
\widehat{e}_{i t}=\varrho \widehat{e}_{i t-1}+\nu_{i t}
$$

The null and alternative hypothesis for the above equation is specified as follows:

$$
\begin{aligned}
& H_{0}: \varrho=1 \\
& H_{1}: \varrho<1
\end{aligned}
$$

The drawback of these tests is that they do not necessitates estimation of the longrun variance-covariance matrix so that to tackle the problem of serial correlation. In an 
alternative test, Dickey and Fuller introduced lags of the dependent variable so that serial correlation in the estimated residual vanish. The equation is specified as follows:

$$
\widehat{e}_{i t}=\varrho \widehat{e}_{i t-1}+\sum_{j=i}^{p}+\phi_{j} \Delta e_{i t-j}+\nu_{i t p}
$$

The ADF test take the form for the null of no co-integration,

$$
t_{A D F}=\frac{(\widehat{\varrho}-1)\left[\sum_{i=1}^{N}\left(e_{i}^{\prime} Q_{i} e_{i}\right)\right]^{1 / 2}}{S_{\nu}}
$$

More calculation of Kao represents the following statistics

$$
A D F=\frac{t_{A D F}+\sqrt{6} N \widehat{o}_{\nu} /\left(2 \widehat{o}_{\nu}\right)}{\sqrt{\widehat{o}_{\nu}^{2} /\left(2 \widehat{o}_{\nu}\right)+3 \widehat{o}_{\nu}^{2} /\left(10 \widehat{o}_{\nu}^{2}\right)}} N(0,1)
$$

\section{Johansen (Combined Individual) Co-integration Test}

Johansen (1988) suggests two diverse approaches, namely the likelihood ratio trace statistics, and the maximum eigenvalue statistics, to determine the presence of co-integration vectors in non-stationary time series. The trace statistics and maximum eigenvalue statistics is algebraically expressed as follows:

$$
\begin{aligned}
& \lambda_{\text {trace }}(r)=-T \sum_{i=r+1}^{n} \ln \left(1-\widehat{\lambda}_{i}\right) \\
& \lambda_{\max }(r, r+1)=-T \ln \left(1-\widehat{\lambda}_{r+1}\right)
\end{aligned}
$$

The null and alternative hypothesis for the trace tests is that there is at most $\mathrm{r}$ cointegration vector against the alternative of full rank $r=n$ co-integration vector. Similarly, the null and alternative hypothesis of maximum eigenvalue statistics is to check the $\mathrm{r}$ cointegrating vectors against the alternative hypothesis of $\mathrm{r}+1$ co-integrating vectors. Applying Johansen (1988) test for co-integration, Maddala and Wu (1999) consider Fisher's recommendation to combine individuals tests, to suggest an alternative to the two earlier tests, for testing of co-integration in the full panel by merging individual cross-sections tests for co-integration. Under the null hypothesis for the entire panel, the individual co-integration test for cross-section $\mathrm{i}$ is given below:

$$
\chi^{2}=-2 \sum_{i=1}^{N} \log _{e}\left(\pi_{i}\right)
$$

The p-values based on $\chi^{2}$-value of McKinnon (1973) for Johansen's co-integration trace test and maximum eigenvalue test is reported by Eviews.

When co-integration among the variables under consideration is confirmed, then panel regression is estimated through two approaches of OLS-based estimators namely FMOLS and DOLS. The standard pooled OLS panel estimator can be written as: 


$$
\widehat{\beta}_{N T}=\left[\sum_{i=1}^{N} \sum_{t=1}^{T}\left(x_{i, t}-\overline{x_{i}}\right)^{2}\right]^{-1} \sum_{i=1}^{N} \sum_{t=1}^{T}\left(x_{i, t}-\overline{x_{i}}\right)\left(y_{i, t}-\overline{y_{i}}\right)
$$

For panel Co-integration analysis Pedroni introduced the application of the FMOLS method. Modification of the standard OLS model for pooled FM-OLS estimator is given as:

$$
\left.\widehat{\beta}_{F M}=\left(\left(\sum_{i=1}^{N}\right) \widehat{L}_{22 i}^{-1} \sum_{t=1}^{T}\left(x_{i, t}-\overline{x_{i}}\right)^{2}\right)\right)^{-1} \sum_{i=1}^{N} \widehat{L}_{11 i}^{-1} \widehat{L}_{22 i}^{-1}\left(\sum_{t=1}^{T}\left(X_{i, t}-\overline{X_{i}}\right) y *_{i, t}-T \widehat{\delta}_{i}\right.
$$

Where, $y *_{i, t}=\left(y_{i, t}-\overline{y_{i}}\right)-\left(\widehat{L}_{21 i}^{-1} / \widehat{L}_{22 i}^{-1}\right) \Delta x_{i, t}+\left(\widehat{L}_{21 i}^{-1}-\widehat{L}_{22 i}^{-1} / \widehat{L}_{22 i}^{-1}\right) \beta\left(x_{i, t}-\overline{x_{i}}\right)$ $\& \widehat{\delta}_{i}=\widehat{\gamma}_{21 i}+\widehat{\omega}_{21 i}^{0}-\left(\widehat{L}_{21 i}^{-1} / \widehat{L}_{22 i}^{-1}\right)\left(\widehat{\gamma}_{21 i}+\widehat{\omega}_{21 i}^{0}\right)$

Pedroni stressed that the dynamic co-integrated panels are estimated so that to address the issue of heterogeneity along with differences in means among the individuals and differences in individuals' responses to short-run disturbances from co-integrating equilibrium. For this purpose, he incorporates into regression the individual specific intercepts together with allowed the serial correlation properties of the error processes to vary across individual members of the panel.

Kao and Chiang (2017) extended the individual time series DOLS estimator to panel analysis by developing finite sample properties of the OLS, DOLS, and Pedroni?s FM-OLS. The following regression equation is used to obtain the DOLS estimator.

$$
y_{i, t}=\beta_{i}^{\prime} x_{i, t}+\sum_{j=-q}^{q} \zeta_{i j} \Delta x_{i, t+j}+\gamma_{l i}^{\prime} D_{l i}+\epsilon_{i, t}
$$

For the information criteria, $\mathrm{q}$ is used to choose the numbers of leads/lags. Infinite samples, DOLS performs better than both the OLS and the FMOLS estimators in terms of unbiased estimation. Because of the differences in regressors due to the lead/lag effect, the DOLS estimator has the additional advantage of controlling endogeneity in the model by suppressing the endogenous feedback (Lean \& Smyth, 2010). Thus, the DOLS estimation method provides a robust correction of endogeneity in the explanatory variables (Afonso \& Jalles, 2012).

\section{Data, Data Description and Results in Discussion}

This study uses country-level data for the 9 Asia-Pacific region ${ }^{3}$ from 1998 to 2017 . We use three kinds of variables in this study. The first kind is the seven dependent variables all are indices including financial market depth index, financial market efficiency index, financial market access index, financial institution depth index, financial institution efficiency index,

\footnotetext{
${ }^{3}$ Countries that are including in the sample comprises of Australia, Bangladesh, India, Indonesia, Japan, Malaysia, Pakistan, Singapore and Thailand.
} 


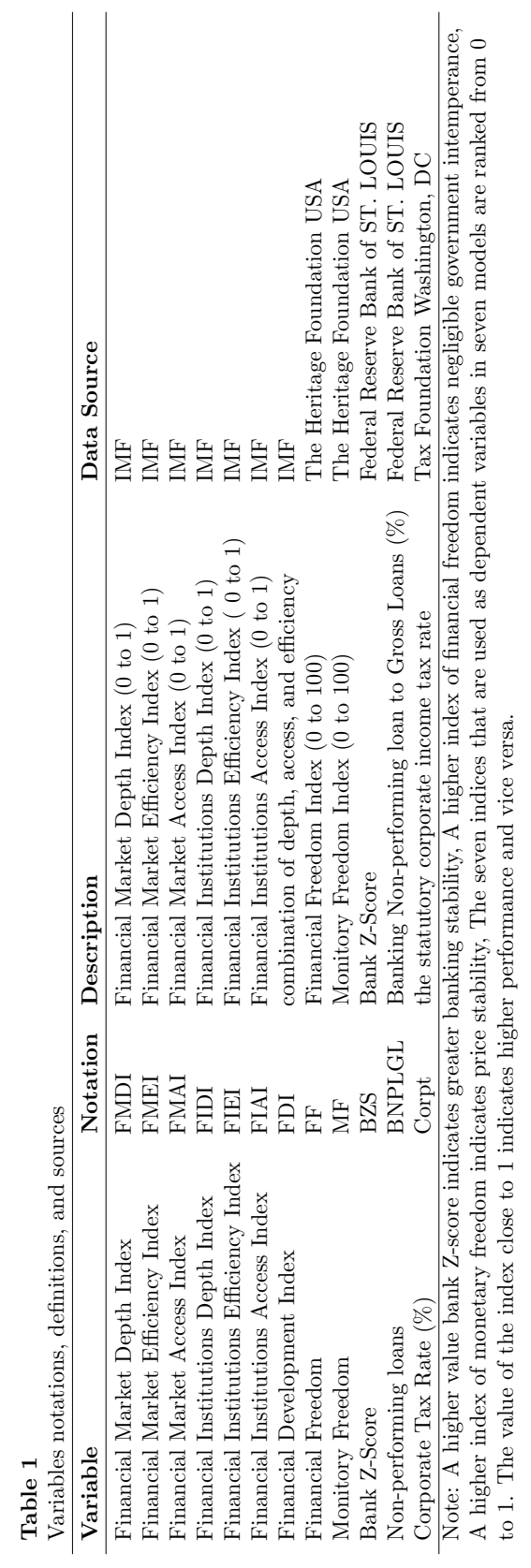


financial institution access index, and financial development index which are obtained from financial development index database by International Monetary Fund ${ }^{4}$. The second kind of variables is the bank-specific variables such as Bank Z-score and Non-performing loans are derived from the Federal Reserve Bank of ST. LOUIS while the third kind of variable is related to the government regulation of financial, monetary, and corporate sectors of the economy including financial freedom, monetary freedom, and corporate tax rate which are retrieved from the Heritage Foundation USA and the Tax Foundation Washington, DC respectively. The detail of the data is given in table 1 below.

To check for the multicollinearity problem, the correlation matrix was computed for all the variables under consideration and is given in table 2. There is no evidence of high multicollinearity problems except few exceptional cases such as between FDI and FMDI, FMDI and FIDI, FDI and FIDI. The correlation between these variables is greater than 0.9 but the data analyst says that if $\mathrm{r} 0.95$ then collinearity is problematic. Since the $\mathrm{r}$ value for none of the above-mentioned pair of variables is greater than 0.95 , so our interpretation of the relationship is correct.

Table 2

\begin{tabular}{|c|c|c|c|c|c|c|c|c|c|c|c|c|}
\hline Variables & -1 & -2 & -3 & -4 & -5 & -6 & -7 & -8 & -9 & -10 & -11 & -12 \\
\hline (1) FMDI & 1 & & & & & & & & & & & \\
\hline (2) FMEI & 0.379 & 1 & & & & & & & & & & \\
\hline (3) FDI & 0.926 & 0.531 & 1 & & & & & & & & & \\
\hline (4) FIAI & 0.638 & 0.393 & 0.837 & 1 & & & & & & & & \\
\hline (5) FIEI & 0.624 & 0.163 & 0.705 & 0.666 & 1 & & & & & & & \\
\hline (6) FIDI & 0.936 & 0.296 & 0.944 & 0.734 & 0.709 & 1 & & & & & & \\
\hline (7) FMAI & 0.844 & 0.294 & 0.872 & 0.612 & 0.543 & 0.874 & 1 & & & & & \\
\hline (8) MF & 0.424 & 0.196 & 0.48 & 0.43 & 0.288 & 0.471 & 0.461 & 1 & & & & \\
\hline (9) $\mathrm{FF}$ & 0.284 & 0.033 & 0.31 & 0.314 & 0.126 & 0.301 & 0.358 & 0.532 & 1 & & & \\
\hline (10) CORPT & -0.37 & 0.22 & -0.181 & 0.143 & -0.201 & -0.327 & -0.412 & -0.045 & 0.024 & 1 & & \\
\hline (11) BZS & 0.619 & 0.186 & 0.506 & 0.203 & 0.316 & 0.583 & 0.484 & 0.225 & 0.18 & -0.273 & 1 & \\
\hline (12) BNPL & -0.583 & -0.253 & -0.588 & -0.513 & -0.472 & -0.541 & -0.516 & -0.378 & -0.38 & 0.264 & -0.305 & 1 \\
\hline
\end{tabular}

The results of descriptive statistics including the mean, standard deviation, minimum, maximum, skewness, kurtosis, and Jarque-Bera for each variable are provided in table 3 . Results show that seven variables are negatively skewed i.e. more of the observations lying to the left of the mean value of the series while six variables are positively skewed. Kurtosis tells us about the peakedness of the data. Only four series are leptokurtic while the rest is platykurtic. Similarly, for some of the variables, the Jarque-Bera test is significant which means the particular series is not normally distributed while some of the series are normally distributed.

We applied the four-panel unit root test the results of which are given in table 4 . The results show that all the variables are integrated into order one. Not all of the tests suggest the integration of order one, we made this decision based on majority rule. Out of four tests, if three suggest the integration of order one, we consider the series as integrated of order one. On the majority rule basis, all of the variables are integrated of order one which allows us for the next step of the co-integration test.

\footnotetext{
${ }^{4}$ https://data.imf.org/?sk=F8032E80-B36C-43B1-AC26-493C5B1CD33B
} 
Table 3

\begin{tabular}{lccccccc} 
Descriptive Statistics \\
\hline Variable & Mean & Std. Dev. & Min & Max & Skewness & Kurtosis & Jarque_Bera \\
\hline FMDI & 0.514 & 0.306 & 0.008 & 0.985 & -0.194517 & 1.634651 & $4.86449^{* *}$ \\
FMEI & 0.561 & 0.315 & 0.008 & 1 & -0.066951 & 1.822192 & $10.36307^{*}$ \\
FDI & 0.532 & 0.237 & 0.126 & 0.952 & -0.04285 & 1.74327 & 1.70203 \\
FIAI & 0.384 & 0.29 & 0.079 & 0.917 & 0.725448 & 2.051185 & 2.16443 \\
FIEI & 0.75 & 0.09 & 0.451 & 0.89 & -0.602246 & 2.557774 & $2.1419^{* * *}$ \\
FIDI & 0.462 & 0.326 & 0.053 & 0.971 & 0.027785 & 1.35762 & 1.91618 \\
FMAI & 0.416 & 0.283 & 0.001 & 0.958 & -0.062735 & 2.018127 & 1.22615 \\
MF & 78.085 & 9.566 & 0 & 92.9 & -3.790007 & 29.53388 & $5616.086^{*}$ \\
FF & 54.611 & 18.831 & 10 & 90 & -0.128871 & 2.503295 & 2.309461 \\
CORPT & 30.366 & 6.448 & 17 & 48 & 0.058062 & 3.050611 & 0.118341 \\
BZS & 12.44 & 5.961 & 2.57 & 26.9 & 0.46529 & 2.539796 & $7.948521^{*}$ \\
BNPLGL & 8.585 & 9.485 & 0.4 & 48.6 & 1.890706 & 6.665321 & $204.5358^{*}[1]$ \\
\hline Note: ${ }^{*}$ indicate significance at $1 \%, * *$ indicate significance at $5 \%$ while *** indicate significance \\
at 10\%
\end{tabular}

Table 4

\begin{tabular}{|c|c|c|c|c|c|c|c|c|}
\hline \multirow[t]{2}{*}{ Level } & \multicolumn{2}{|c|}{ LLC } & \multicolumn{2}{|r|}{ IPS } & \multicolumn{2}{|c|}{ Fisher ADF } & \multicolumn{2}{|c|}{ Fisher PP } \\
\hline & Level & Difference & Level & Difference & Level & Difference & Level & Difference \\
\hline \multicolumn{9}{|l|}{ Variables } \\
\hline FMDI & 1.19 & $-6.97^{*}$ & -0.09 & $-5.52^{*}$ & 17.25 & $63.58^{*}$ & $30.35^{* *}$ & $129.62^{*}$ \\
\hline FMEI & 1.78 & $-6.98^{*}$ & $-1.45^{* * *}$ & $-5.32^{*}$ & 21.48 & $39.20^{*}$ & $49.82^{*}$ & 117.23* \\
\hline FDI & $-1.92^{* *}$ & $-6.17^{*}$ & -0.68 & $-4.09^{*}$ & 19.35 & $49.12^{*}$ & 21.06 & $88.20^{*}$ \\
\hline FIAI & -1.01 & -0.33 & 0.63 & $-3.77^{*}$ & 19.18 & $22.5^{*}$ & 6.83 & $33.12^{* *}$ \\
\hline FIEI & $45.89^{*}$ & $103.8^{*}$ & $-1.56^{* * *}$ & $-3.32^{*}$ & $32.55^{* *}$ & $42.52^{*}$ & $45.89^{*}$ & $103.8^{*}$ \\
\hline FMAI & -0.89 & $-5.40^{*}$ & -0.72 & $-5.56^{*}$ & 21.78 & $64.32^{*}$ & $30.13^{* *}$ & $97.72^{*}$ \\
\hline FIDI & 0.24 & $-1.34 * *$ & 159 & $-4.47^{*}$ & 14.52 & $54.48^{*}$ & 21.23 & $498.5^{*}$ \\
\hline $\mathrm{FF}$ & $-2.16^{* *}$ & $-5.46^{*}$ & $-1.56^{* *}$ & $-5.46^{*}$ & 24.71 & $62.78^{*}$ & $26.87^{* * *}$ & $135.74^{*}$ \\
\hline CORPT & $-3.00^{*}$ & $-3.97^{*}$ & -0.92 & $-4.82^{*}$ & $28.33^{* *}$ & $56.23^{*}$ & $37.98^{*}$ & $101.5^{*}$ \\
\hline $\mathrm{BZS}$ & $-1.77^{* *}$ & $-5.56^{*}$ & $-2.33^{*}$ & $-6.69^{*}$ & $37.08^{*}$ & $77.83^{*}$ & $50.22^{*}$ & $358^{*}$ \\
\hline BNPLGL & $-4.44^{*}$ & $-7.97^{*}$ & $-2.80^{*}$ & $-4.80^{*}$ & 21.07 & $49.81^{*}$ & 22.9 & $61.81^{*}$ \\
\hline $\mathrm{MF}$ & 6.08 & $-3.62^{*}$ & 1.63 & $-3.01 *$ & 14.71 & $39.44^{*}$ & 10.72 & $71.22^{*}$ \\
\hline
\end{tabular}

For all the models/equations the results of three co-integration tests namely (Kao, 1999; Pedroni, 1999; Johansen, 1988) Fisher panel Co-integration tests are given in table 5, table 6 and in table 7 respectively. The specification of optimal lag length in the Kao (1999) test was selected based on the minimum value of Akaike Information Criteria. The p-value in all the specifications is less than $5 \%$ except specification 3. This suggests that there is strong evidence of a long-run relationship among the variables under consideration for all the models except model 3.

The Pedroni panel co-integration test results for the seven specifications are given in table 6 below. The seven test statistics introduced by Pedroni (1999) to test the null hypothesis of no co-integration allows heterogeneity in the nonstationary panel. The seven test statistics are categorized into group mean statistics and the panel statistics where the former is the average of individual country test statistics while the latter pool the test statistics along within the dimension. Out of seven test statistics, four test statistics suggest co-integration among variables while three do not for six specifications/equations. For specification two in table 6 , there is no evidence of long-run relationships among variables. 


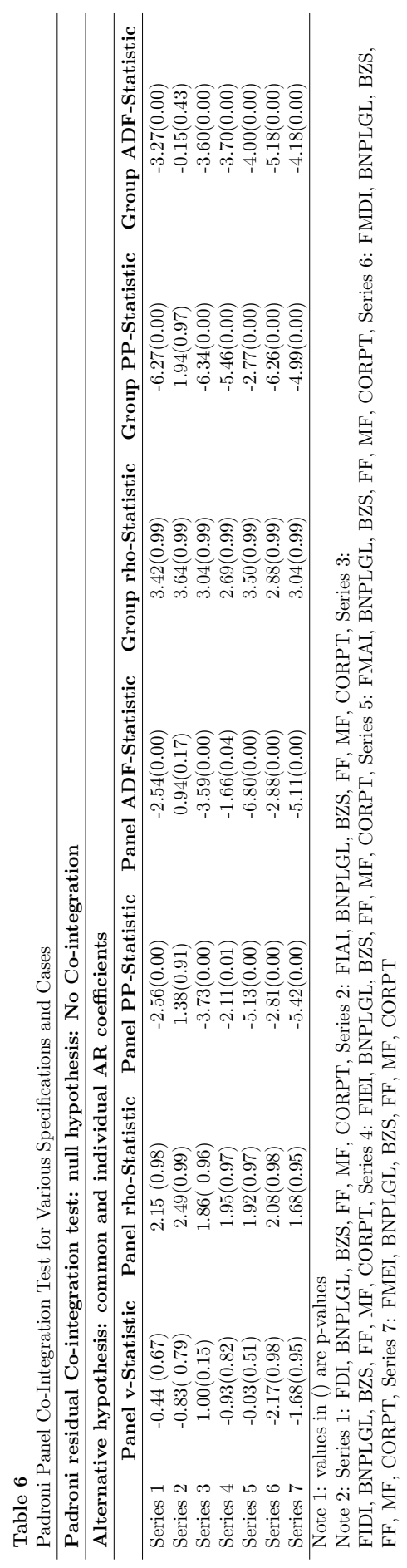


Table 7

The Fisher Combined Co-integration Test for Various Specifications

\begin{tabular}{|c|c|c|c|c|c|}
\hline \multirow[t]{2}{*}{ Models } & \multicolumn{3}{|c|}{ Panel A: Trace Test } & \multicolumn{2}{|c|}{ Panel B: Max-Eigenvalue Test } \\
\hline & & & P-Value & $\begin{array}{c}\text { Max Eigen } \\
\text { value Test }\end{array}$ & P-Value \\
\hline \multirow[t]{6}{*}{ Model 1: Financial Development Index } & None & 80.61 & 0.0000 & 80.61 & 0.000 \\
\hline & At most 1 & 283.0 & 0.0000 & 200.6 & 0.000 \\
\hline & At most 2 & 286.1 & 0.0000 & 170.2 & 0.000 \\
\hline & At most 3 & 179.0 & 0.0000 & 106.8 & 0.000 \\
\hline & At most 4 & 101.9 & 0.0000 & 69.89 & 0.000 \\
\hline & At most 5 & 74.66 & 0.0000 & 74.66 & 0.000 \\
\hline \multirow[t]{6}{*}{ Model 2: Financial Institutions Access Index } & None & 80.61 & 0.0000 & 80.61 & 0.000 \\
\hline & At most 1 & 333.7 & 0.0000 & 254.0 & 0.000 \\
\hline & At most 2 & 275.5 & 0.0000 & 209.3 & 0.000 \\
\hline & At most 3 & 121.4 & 0.0000 & 77.20 & 0.000 \\
\hline & At most 4 & 66.74 & 0.0000 & 47.12 & 0.002 \\
\hline & At most 5 & 51.28 & 0.0000 & 51.28 & 0.000 \\
\hline \multirow[t]{6}{*}{ Model 3: Financial Institutions Depth Index } & None & 80.61 & 0.0000 & 80.61 & 0.000 \\
\hline & At most 1 & 355.3 & 0.0000 & 258.5 & 0.000 \\
\hline & At most 2 & 291.6 & 0.0000 & 173.5 & 0.000 \\
\hline & At most 3 & 172.8 & 0.0000 & 102.5 & 0.000 \\
\hline & At most 4 & 100.7 & 0.0000 & 75.19 & 0.000 \\
\hline & At most 5 & 62.73 & 0.0000 & 62.73 & 0.000 \\
\hline \multirow[t]{6}{*}{ Model 4: Financial Institutions Efficiency Index } & None & 114.7 & 0.0000 & 114.7 & 0.000 \\
\hline & At most 1 & 279.0 & 0.0000 & 193.0 & 0.000 \\
\hline & At most 2 & 277.1 & 0.0000 & 206.2 & 0.000 \\
\hline & At most 3 & 136.8 & 0.0000 & 97.37 & 0.000 \\
\hline & At most 4 & 65.80 & 0.0000 & 48.42 & 0.001 \\
\hline & At most 5 & 50.08 & 0.0001 & 50.08 & 0.001 \\
\hline \multirow[t]{6}{*}{ Model 5: Financial Market Access Index } & None & 29.51 & 0.0425 & 29.51 & 0.042 \\
\hline & At most 1 & 321.1 & 0.0000 & 242.3 & 0.000 \\
\hline & At most 2 & 258.9 & 0.0000 & 157.4 & 0.000 \\
\hline & At most 3 & 144.3 & 0.0000 & 87.43 & 0.000 \\
\hline & At most 4 & 80.89 & 0.0000 & 55.66 & 0.000 \\
\hline & At most 5 & 65.34 & 0.0000 & 65.34 & 0.000 \\
\hline \multirow[t]{6}{*}{ Model 6: Financial Market Depth Index } & None & 79.23 & 0.0000 & 97.65 & 0.000 \\
\hline & At most 1 & 348.6 & 0.0000 & 264.9 & 0.000 \\
\hline & At most 2 & 244.5 & 0.0000 & 167.1 & 0.000 \\
\hline & At most 3 & 131.0 & 0.0000 & 82.93 & 0.000 \\
\hline & At most 4 & 70.68 & 0.0000 & 51.20 & 0.000 \\
\hline & At most 5 & 56.13 & 0.0000 & 56.13 & 0.000 \\
\hline \multirow[t]{6}{*}{ Model 7: Financial Market Efficiency Index } & None & 80.61 & 0.0000 & 80.61 & 0.000 \\
\hline & At most 1 & 316.3 & 0.0000 & 246.7 & 0.000 \\
\hline & At most 2 & 281.5 & 0.0000 & 192.0 & 0.000 \\
\hline & At most 3 & 141.0 & 0.0000 & 94.24 & 0.000 \\
\hline & At most 4 & 74.46 & 0.0000 & 52.58 & 0.000 \\
\hline & At most 5 & 56.46 & 0.0000 & 56.46 & 0.000 \\
\hline
\end{tabular}

\section{Evidence from FMOLS and DOLS regarding the Long-Run Dy- namic Relationship between Variables}

After testing for the long-run relationship among variables, the next step is to determine the impact of two (government regulation of financial services and bank-specific variables) kind of independent variables on seven financial inclusion indices (markets and institutions indices). The results from both FMOLS and DOLS for the pool of 9 countries belongs to the Asia Pacific region are provided in table 8. The first three columns of the table represent results from FMOLS while the last three columns represent results from DOLS regression. We have seven-panel in table 8, each panel represents the results of each 
model/specification. In each specification/model we change only the dependent variable to examine how it is been impacted by the bank-specific variables and variables determined by government regulation and government control over prices.

Regarding the significance of variables, the results of FMOLS are more consistent than DOLS for all the specifications. However, signs of the coefficients are inconsistent in both FMOLS and DOLS regression results. In DOLS regression, two of the independent variables in models 4 and 7 are insignificant. In model 4 those two independent variables are bank non-performing loans and bank Z-score while in model 7 the two independent variables are bank Z-score and corporate tax rate. Only one variable i.e. corporate tax rate in model 6 is insignificant. On the other hand, in FMOLS regression corporate tax rate in the model and financial freedom in model 4 is insignificant.

In any country, the size of the financial sector (measured by bank size, financial institutions, and financial markets) relative to the economy is captured by financial depth. In model 1 the sign of bank non-performing loans to total gross loans is negative in both FMOLS and DOLS regression signifies that the agent's late payment increases the company's risk and as a result negative impact on stock prices. So increasing non-performing loans of the banking sector would have an adverse impact on the financial sector of the economy. Similar results were found by Paul, Devi, and Teh (2012) for Malaysia and Jordan respectively. The bank Z-score is positively and significantly associated with financial market depth in both FMOLS and DOLS regression but the significance level is $10 \%$ in DOLS regression. This is so because the higher value of bank Z-score means greater banking stability (low default probability). An increase in corporate taxation discourages business activities. Albulescu and Ionescu (2018) also found a positive and significant impact of bank stability on financial development in a study for 16 European countries. Reduced business activities mean less financial dealings and so negative impact on financial market depth, our results are consistent with these conceptual/theoretical underpinnings. The government efficient regulation of the country's financial services and balanced control over prices can encourage financial depth. On the other hand, if government interference in the regulation of financial institutions is higher, which in turn influences the credit allocation to a different sector of the economy can negatively influence the financial depth of the economy. In FMOLS and DOLS regressions both financial freedom and monetary freedom have a positive and significant impact on financial market depth.

In model 2, we regress the same independent variables on overall financial development (access, efficiency, and depth) to know how overall financial development can be influenced by bank-specific variables and financial and monetary freedom variables. In FMOLS regression the sign and significance for all the variables are the same as in model 1 while in DOLS regression financial freedom has no significant impact on the overall financial market. This may be because too much regulation of financial institutions and financial markets by the government indicates the difficulty for people and businesses to effectively access financing opportunities. 
Table 8

Estimation Results of Panel FMOLS and Panel DOLS methods

\begin{tabular}{|c|c|c|c|c|c|c|}
\hline \multirow{2}{*}{$\begin{array}{l}\text { Method } \\
\text { Model 1: FMDI }\end{array}$} & \multicolumn{3}{|c|}{ Panel FMOLS } & \multicolumn{3}{|c|}{ Panel DOLS } \\
\hline & Coef. & t-Statistic & P-value & Coef. & t-Statistic & P-value \\
\hline BNPLGL & -0.14 & -10.77 & 0.00 & -0.07 & -4.18 & 0.00 \\
\hline BZS & 0.16 & 21.58 & 0.00 & 0.09 & 1.68 & 0.09 \\
\hline CORPT & -0.22 & -132.01 & 0.00 & -0.25 & -1.91 & 0.05 \\
\hline $\mathrm{FF}$ & 0.03 & 20.89 & 0.00 & -0.12 & -1.69 & 0.09 \\
\hline MF & 0.26 & 176.78 & 0.00 & 0.39 & 4.04 & 0.00 \\
\hline R-squared & 0.527 & & & 0.518 & & \\
\hline Adjut R-squared & 0.515 & & & 0.315 & & \\
\hline Model 2:FDI & Coef. & t-Statistic & P-value & Coef. & t-Statistic & $\mathrm{P}$-value \\
\hline BNPLGL & -0.1 & -8.29 & 0.00 & -0.03 & -1.86 & 0.07 \\
\hline BZS & -0.01 & -1.65 & 0.09 & -0.07 & -1.85 & 0.08 \\
\hline CORPT & -0.02 & -13.66 & 0.00 & -0.27 & -3.29 & 0.00 \\
\hline $\mathrm{FF}$ & 0.03 & 22.55 & 0.00 & 0.02 & 1.37 & 0.18 \\
\hline MF & 0.15 & 102.44 & 0.00 & 0.2 & 3.73 & 0.00 \\
\hline R-squared & 0.392 & & & 0.762 & & \\
\hline Adjut R-squared & 0.376 & & & 0.577 & & \\
\hline Model 3:FIAI & Coef. & t-Statistic & P-value & Coef. & t-Statistic & $\mathrm{P}$-value \\
\hline BNPLGL & -0.18 & -13.74 & 0.00 & -0.08 & -3.84 & 0.00 \\
\hline BZS & -0.1 & -13.69 & 0.00 & -0.12 & -4.56 & 0.00 \\
\hline CORPT & 0.41 & 1.45 & 0.1 & -0.88 & -11.66 & 0.00 \\
\hline $\mathrm{FF}$ & -0.03 & -20.85 & 0.00 & -0.4 & -8.53 & 0.00 \\
\hline MF & -0.1 & -71.61 & 0.00 & -0.21 & -3.32 & 0.01 \\
\hline R-squared & 0.323 & & & 0.975 & & \\
\hline Adjut R-squared & 0.306 & & & 0.638 & & \\
\hline Model 4:FIDI & Coef. & t-Statistic & $\mathrm{P}$-value & Coef. & t-Statistic & P-value \\
\hline BNPLGL & -0.154096 & -5.43 & 0.00 & 0.02 & 0.62 & 0.54 \\
\hline BZS & -0.239201 & -4.5 & 0.00 & -0.44 & -13.31 & 0.00 \\
\hline CORPT & -0.208545 & -1.76 & 0.07 & 0.1 & 1.76 & 0.11 \\
\hline $\mathrm{FF}$ & -0.091865 & -1.19 & 0.23 & -0.34 & -6.02 & 0.00 \\
\hline MF & 0.275985 & 2.51 & 0.01 & 0.12 & 2.16 & 0.06 \\
\hline R-squared & 0.623 & & & 0.992 & & \\
\hline Adjut R-squared & 0.614 & & & 0.884 & & \\
\hline Model 5:FIEI & Coef. & t-Statistic & P-value & Coef. & t-Statistic & P-value \\
\hline BNPLGL & -0.09 & -7.41 & 0.00 & -0.02 & -3.13 & 0.01 \\
\hline BZS & -0.26 & -35.45 & 0.00 & -0.07 & -8.8 & 0.00 \\
\hline CORPT & 0 & -3.14 & 0.00 & -0.15 & -8.52 & 0.00 \\
\hline $\mathrm{FF}$ & 0 & -1.68 & 0.09 & -0.13 & -10.71 & 0.00 \\
\hline MF & 0.21 & 146.29 & 0.00 & 0.14 & 9.37 & 0.00 \\
\hline R-squared & 0.889 & & & 0.984 & & \\
\hline Adjut R-squared & 0.742 & & & 0.773 & & \\
\hline Model 6:FMEI & Coef. & t-Statistic & $\mathrm{P}$-value & Coef. & t-Statistic & $\mathrm{P}$-value \\
\hline BNPLGL & -0.14 & -11.01 & 0.00 & -0.05 & -7.13 & 0.00 \\
\hline BZS & -0.07 & -9.46 & 0.00 & -0.12 & -3.93 & 0.00 \\
\hline CORPT & -0.22 & -129.02 & 0.00 & -0.07 & -1.13 & 0.28 \\
\hline $\mathrm{FF}$ & -0.03 & -18.27 & 0.00 & -0.07 & -2.12 & 0.04 \\
\hline MF & 0.26 & 178.58 & 0.00 & 0.1 & 1.96 & 0.05 \\
\hline R-squared & 0.616 & & & 0.921 & & \\
\hline Adjut R-squared & 0.383 & & & 0.885 & & \\
\hline Model 7:FMAI & Coef. & t-Statistic & $\mathrm{P}$-value & Coef. & t-Statistic & $\mathrm{P}$-value \\
\hline BNPLGL & -0.18 & -13.66 & 0.00 & -0.02 & -10.2 & 0.06 \\
\hline BZS & -0.01 & -2.58 & 0.01 & -0.36 & -4.19 & 0.14 \\
\hline CORPT & -0.3 & -179.24 & 0.00 & -0.91 & -4.45 & 0.14 \\
\hline $\mathrm{FF}$ & 0.02 & 11.72 & 0.00 & -0.41 & -29.17 & 0.02 \\
\hline $\mathrm{MF}$ & 0.33 & 223.49 & 0.00 & 1.67 & 34.05 & 0.01 \\
\hline R-squared & 0.176 & & & 0.921 & & \\
\hline Adjut R-squared & 0.156 & & & 0.738 & & \\
\hline
\end{tabular}


The dependent variable in model 3 is the financial institutions access the index. This index is constructed from Bank branches per 100,000 adults and ATMs per 100,000 adults. In model 3 all the variables are significant in both the FMOLS and DOLS regression, but the signs of financial freedom and monetary freedom are negative in both the regressions. Also, the sign of corporate tax rate is unusual in FMOLS regression but it is insignificant. The justification of the signs of the last two variables comes from the fact of too much regulation of price control and financial markets and financial institutions by the government hurts access to financial institutions.

In model 4, we use the financial institution's depth index as the dependent variable. This index is constructed from four variables including Private-sector credit to GDP, Pension fund assets to GDP, Mutual fund assets to GDP, Insurance premiums, life and non-life to GDP. In FMOLS regression, the financial freedom index has an incorrect sign but is insignificant. All the remaining variables are significant and have correct signs. However, in DOLS regression non-performing loans and corporate tax rates has insignificant results on the financial institution's depth index.

The dependent variable in model 5 is the financial institutions' efficiency index which is constructed from Net interest margin, Lending-deposits spread, Non-interest income to total income, Overhead costs to total assets, Return on Assets, and Return on equity. All the variables in both the model are significant and have the same signs. One exception is the negative sign associated with the financial freedom index which again can be linked with tight regulation of financial institutions by the government.

The dependent variable in model 6 i.e. financial market efficiency is measured by the Stock market turnover ratio. The results of this model are the same as those of model 5 in terms of variables' significance and signs. The one exception is that the corporate tax rate is insignificant in DOLS regression. In the last model, we regress the independent variables on the financial market access index. All the variables in the FMOLS regression are significant and have the correct sign. IN DOLS regression two of the independent variables are bank $\mathrm{Z}$-score and corporate tax rate.

After determining the long-run relationship among variables in 7 models and the underlying dynamic long-run estimation, the short-run causality among the variables is calculated in the next step through Dumitrescu and Hurlin (2012) panel causality test approach. This approach is considered superior in the sense that it takes into account heterogeneity across cross-sections meaning that parameters will vary across the cross-sections. The average Wald statistic of Dumitrescu and Hurlin (2012) is given as follows:

$$
W_{N, T}^{H n c}=N^{-1} \sum_{i=1}^{N} W_{i, T}
$$

$W_{i, T}$ represent the individual Wald statistics for ith cross-section units, where the null hypothesis is

$$
H_{0}: \varphi_{i}=0
$$

However, Dumitrescu and Hurlin (2012) maintain that in small sample cases the average Wald statistic does not follow the standard chi-square distribution. In such a case 
the alternative test-statistic proposed by Dumitrescu and Hurlin (2012) is the asymptotic standardized statistic defined as follows:

$$
z_{N}^{H N C}=\frac{\sqrt{\left.N\left[W_{N, T}^{H n c}-N^{-1} \sum_{i=1}^{N} W_{i, T}\right)\right]}}{\sqrt{N^{-1} \sum_{i=1}^{N}} \operatorname{var}\left(W_{i, T}\right)} \rightarrow N(0,1)
$$

Table 9 contains the results of the (Dumitrescu \& Hurlin, 2012) panel causality test.

Test results show that there is one-way causality from non-performing loans to the overall financial development index in 9 countries from the Asia Pacific region. Two-way causality exists between three pairs of variables. This two-way causality exists between financial freedom and non-performing loans, between financial institutions' depth and nonperforming loans, and between financial market depth and bank Z-score. Corporate tax rate and financial institution efficiency also homogeneously causes bank Z-score. Similarly, one-way causality exists from bank Z-score, corporate tax rate, and financial market depth to financial freedom. Financial institution depth homogeneously causes monetary freedom while financial freedom causes financial institution efficiency.

Table 9

Results of panel heterogeneous test

\begin{tabular}{lccc}
\hline Null Hypothesis: & W-Stat. & Zbar-Stat. & Prob. \\
\hline FDI does not homogeneously cause BNPLGL & 3.40751 & 1.07475 & 0.2825 \\
BNPLGL does not homogeneously cause FDI & 5.32430 & 3.07317 & 0.0021 \\
FF does not homogeneously cause BNPLGL & 5.14418 & 2.88538 & 0.0039 \\
BNPLGL does not homogeneously cause FF & 4.90906 & 2.64025 & 0.0083 \\
FIDI does not homogeneously cause BNPLGL & 4.32917 & 2.03567 & 0.0418 \\
BNPLGL does not homogeneously cause FIDI & 5.16425 & 2.90630 & 0.0037 \\
CORPT does not homogeneously cause BZS & 5.19873 & 2.99404 & 0.0028 \\
BZS does not homogeneously cause CORPT & 2.72332 & 0.37985 & 0.7041 \\
FF does not homogeneously cause BZS & 3.63624 & 1.34396 & 0.1790 \\
BZS does not homogeneously cause FF & 5.58504 & 3.40201 & 0.0007 \\
FIEI does not homogeneously cause BZS & 11.3689 & 9.51017 & 0.0000 \\
BZS does not homogeneously cause FIEI & 2.92119 & 0.58881 & 0.5560 \\
FMAI does not homogeneously cause BZS & 4.17760 & 1.91566 & 0.0554 \\
BZS does not homogeneously cause FMAI & 1.31993 & -1.10222 & 0.2704 \\
FMDI does not homogeneously cause BZS & 5.57089 & 3.38707 & 0.0007 \\
BZS does not homogeneously cause FMDI & 4.71428 & 2.48243 & 0.0130 \\
FF does not homogeneously cause CORPT & 1.59547 & -0.81123 & 0.4172 \\
CORPT does not homogeneously cause FF & 68.6185 & 69.9694 & 0.0000 \\
FIAI does not homogeneously cause CORPT & 3.74078 & 1.45435 & 0.1458 \\
CORPT does not homogeneously cause FIAI & 12.5792 & 10.7883 & 0.0000 \\
FMAI does not homogeneously cause CORPT & 4.19188 & 1.93074 & 0.0535 \\
CORPT does not homogeneously cause FMAI & 3.18397 & 0.86632 & 0.3863 \\
FMDI does not homogeneously cause CORPT & 3.90964 & 1.63267 & 0.1025 \\
CORPT does not homogeneously cause FMDI & 5.26814 & 3.06734 & 0.0022 \\
FMEI does not homogeneously cause CORPT & 4.07082 & 1.80290 & 0.0714 \\
CORPT does not homogeneously cause FMEI & 2.71877 & 0.37505 & 0.7076 \\
FIEI does not homogeneously cause FF & 2.26816 & -0.10083 & 0.9197 \\
FF does not homogeneously cause FIEI & 13.3365 & 11.5880 & 0.0000 \\
FMDI does not homogeneously cause FF & 5.20138 & 2.99684 & 0.0027 \\
FF does not homogeneously cause FMDI & 1.79389 & -0.60169 & 0.5474 \\
MF does not homogeneously cause FIDI & 1.40140 & -1.01618 & 0.3095 \\
FIDI does not homogeneously cause MF & 5.29258 & 3.09315 & 0.0020 \\
\hline
\end{tabular}




\section{Conclusion and Policy Recommendations}

Although a plethora of work can be found to investigate the impact of financial development on economic growth, income inequality, and other macroeconomic variables, the literature is very scant to examine the relationship between financial regulation/liberalization, monetary freedom, and financial development. Also, the existing literature examines the impact of these variables on only one aspect of financial development i.e. either on financial inclusion, overall financial development, or on bank risk-taking among others, while ignoring its relationship with sub-indices of financial development. On this backdrop, this study investigated the long-run dynamic relationship between financial freedom, monetary freedom, and optimal policy instrument of corporate tax rate with overall financial development index and its six sub-indices using data from 9 Asia-pacific region countries. Three kinds of empirical analysis are used in this study. For testing the long-run relationship between variables under consideration, the Pedroni and Kao (Engle-Granger-based) and the Fisher (combined Johansen) panel co-integration test were used. For quantifying the relationship, the FMOLS and DOLS methods are used to examine the long-run dynamic relationship in seven models of the study. The paper also applied the causality technique to validate the coefficients in the FMOLS and DOLS estimation.

We found through panel co-integration tests that there exist long-run relationships among variables included in all seven models. Since all the indices of financial development included in this study are computed from different indicators, therefore they are influenced differently by the same variables in a different model of the study. For example in FMOLS regressions, financial regulation and control over prices by the government or non-government agencies improve the financial market depth index, overall financial development index, and financial market access index and deteriorate the financial institution access index. Financial freedom improves the financial institution's depth index, financial institutions efficiency index, and financial market efficacy index while monetary freedom deteriorates these three indices. The most important to note is that monetary freedom improves all seven indices. The results of DOLS are consistent with the FMOLS only for the financial market depth index model. In the financial development index model, the sign is the same but financial freedom is not statistically significant. In the financial institution access and financial intuition depth model the sign of corporate tax rate and bank non-performing loans is not consistent with FMOLS results. Results from the causality test indicate that there exists two-way causality between financial freedom and bank non-performing loan, financial institution depth index and bank non-performing loan and between financial market depth index and bank Z-score.

A number of implications can be deduced from the findings of this study. First and foremost is that the countries in the Asia-pacific region should focus on the stability of their financial system through restoring the confidence of investors, protect 'their depositors and market as well as resolving the problem of the credit crunch. Another important area to which the region should divert its attention is to build an effective regulatory capital framework. Regulation instruments such as portfolio restrictions and reserve requirements, deposited interest rate ceiling, deposited insurance and capital requirement along with entry and merger restrictions if utilized properly and effectively can help to resolve the 
issue of market failure and can strengthen the whole financial infrastructure and vice versa. Moreover, to determine the optimal policy instrument i.e. optimal corporate tax rate that strengthens the financial development of the country, a coordination reform between the tax policy unit and the tax administration unit is a must. 


\section{References}

Afonso, A., \& Jalles, J. T. (2012). Revisiting fiscal sustainability: Panel cointegration and structural breaks in OECD countries.

Albulescu, C. T., \& Ionescu, A. M. (2018). The long-run impact of monetary policy uncertainty and banking stability on inward fdi in eu countries. Research in International Business and Finance, 45, 72-81.

Badeeb, R. A., Lean, H. H., et al. (2017). The determinants of financial development in the republic of yemen: Evidence from the principal components approach. Capital Market Review, 25(2), 32-48.

Beck, T., Demirgüç-Kunt, A., \& Levine, R. (2000). A new database on the structure and development of the financial sector. The World Bank Economic Review, 14(3), 597-605.

Beck, T., Demirgüç-Kunt, A., \& Levine, R. (2006). Bank concentration, competition, and crises: First results. Journal of Banking \& Finance, 30(5), 1581-1603.

Bekaert, G., Harvey, C. R., \& Lundblad, C. (2005). Does financial liberalization spur growth? Journal of Financial Economics, 77(1), 3-55.

Bhattacharyya, S., \& Hodler, R. (2014). Do natural resource revenues hinder financial development? the role of political institutions. World Development, 57, 101-113.

Bittencourt, M. (2012). Financial development and economic growth in Latin America: Is schumpeter right? Journal of Policy Modeling, 34(3), 341-355.

Boyd, J. H., \& De Nicolo, G. (2005). The theory of bank risk taking and competition revisited. The Journal of Finance, 60(3), 1329-1343.

Boyd, J. H., Levine, R., \& Smith, B. D. (2001). The impact of inflation on financial sector performance. Journal of Monetary Economics, 47(2), 221-248.

Bui, D.-T. (2018). How financial freedom and integration change public debt impact on financial development in the Asia-Pacific: a panel smooth transition regression approach. Australian Economic Review, 51(4), 486-501.

Carlsson, F., \& Lundström, S. (2002). Economic freedom and growth: Decomposing the effects. Public Choice, 112(3), 335-344.

Christensen, J. (2005). Domestic debt markets in sub-saharan africa. IMF Staff Papers, 52(3), 518-538.

Dumitrescu, E.-I., \& Hurlin, C. (2012). Testing for granger non-causality in heterogeneous panels. Economic modelling, 29(4), 1450-1460.

Gylfason, T., \& Zoega, G. (2006). Natural resources and economic growth: The role of investment. World Economy, 29(8), 1091-1115.

Henry, P. B. (2000). Stock market liberalization, economic reform, and emerging market equity prices. The Journal of Finance, 55(2), 529-564.

Huang, Y. (2010). Political institutions and financial development: an empirical study. World Development, 38(12), 1667-1677.

Ivanović, V., \& Stanišić, N. (2017). Monetary freedom and economic growth in new european union member states. Economic research-Ekonomska istraživanja, 30(1), 453-463. 
Johansen, S. (1988). Statistical analysis of cointegration vectors. Journal of Economic Dynamics and Control, $12(2-3), 231-254$.

Kao, C. (1999). Spurious regression and residual-based tests for cointegration in panel data. Journal of Econometrics, 90(1), 1-44.

Kodongo, O. (2018). Financial regulations, financial literacy, and financial inclusion: Insights from Kenya. Emerging Markets Finance and Trade, 54(12), 2851-2873.

Law, S. H., Azman-Saini, W., \& Ibrahim, M. H. (2013). Institutional quality thresholds and the finance-growth nexus. Journal of Banking \& Finance, 37(12), 5373-5381.

Lean, H. H., \& Smyth, R. (2010). Co2 emissions, electricity consumption and output in ASEAN. Applied Energy, 87(6), 1858-1864.

McKinnon, R. I. (1973). Money and capital in economic development. Washington D.C. Brookings Institution.

Paul, S. Y., Devi, S. S., \& Teh, C. G. (2012). Impact of late payment on firms' profitability: Empirical evidence from Malaysia. Pacific-Basin Finance Journal, 20(5), 777-792.

Pedroni, P. (1999). Critical values for cointegration tests in heterogeneous panels with multiple regressors. Oxford Bulletin of Economics and Statistics, 61(S1), 653-670.

Roe, M. J., \& Siegel, J. I. (2011). Political instability: Effects on financial development, roots in the severity of economic inequality. Journal of Comparative Economics, $39(3), 279-309$. 